\title{
INTEGRATED APPROACH FOR LIMING AND FERTILIZER APPLICATION ON YIELD OF CABBAGE AND CAULIFLOWER IN ACIDIC SOIL OF SYLHET
}

\author{
M. I. Nazrul* and M. R. Shaheb \\ On-Farm Research Division (OFRD), Bangladesh Agricultural Research Institute (BARI), Sylhet, \\ Bangladesh \\ *Corresponding authors: mi_nazrul@yahoo.com
}

Key words: Acid soil, benefit cost ratio, cabbage, cauliflower, liming, dolomite

\begin{abstract}
An experiment was conducted at farming system research and development (FSRD) site, Jalalpur and multi location testing (MLT) sites, Moulvibazar and Zokigonj during 2013-2015 to study the effect of liming and fertilizers levels on the yield of cabbage and cauliflower in acidic soil of Sylhet. Trials were laid out in a factorial randomized block design with six dispersed replications. The treatments of fertilizer managements were $M_{1}$ : soil test based (STB) recommended fertilizer and $M_{2}$ : fertilizer dose practiced by the farmers (FP) and the level of limes were $L_{1}: 0 t \mathrm{tha}^{-1}$; $\mathrm{L}_{2}: 1 \mathrm{t} \mathrm{ha}^{-1}$ and $\mathrm{L}_{3}: 2 \mathrm{tha} \mathrm{t}^{-1}$. Results revealed that yields of cabbage and cauliflower responded significantly to fertilizer doses, levels of lime, and their combinations in all the locations. Soil test based fertilizer rate $\left(\mathrm{M}_{1}-\mathrm{N}_{201}, \mathrm{P}_{63}, \mathrm{~K}_{65}, \mathrm{~S}_{23}, \mathrm{Zn}_{0.5}\right.$ for cabbage and $\mathrm{M}_{1}-\mathrm{N}_{157}, \mathrm{P}_{57}, \mathrm{~K}_{116}, \mathrm{~S}_{20}, \mathrm{Zn}_{0.5} \mathrm{Kg}$ ha ${ }^{-1}$ for cauliflower) gave the maximum head and curd yields of cabbage and cauliflower, respectively. The levels of lime at the rate $2 \mathrm{t} \mathrm{ha}^{-1}\left(\mathrm{~L}_{3}\right)$ provided the highest yields of cabbage and cauliflower in all locations. Dolomite lime @ $2 t \mathrm{th}^{-1}$ in combination with recommended fertilizer $\left(M_{1} L_{3}\right)$ gave the highest yields and maximum economic returns of cabbage and cauliflower in all locations. However, it was identical with $1 \mathrm{t} \mathrm{ha}^{-1}$ of dolomite lime of similar dose of fertilizer nutrients. Therefore, application of lime at the rate $1 \mathrm{t} \mathrm{ha}^{-1}$ with STB recommended fertilizer management $\left(\mathrm{M}_{1}\right)$ could be enough for profitable economic returns for cultivating cabbage and cauliflower in strongly acidic soil in Sylhet.
\end{abstract}

\section{Introduction}

Acidification of soils is an important challenge for some areas of Bangladesh because of their adverse effects on soil fertility, crop production and food security. At present more than 30 per cent lands of this country have acidity constraint for crop production which is either very strongly acidic $(\mathrm{pH}<4.5)$, strongly acidic $(\mathrm{pH} 4.5-5.5)$ or slightly acidic $(\mathrm{pH} 5.5-6.5)$ (FRG, 2012). The Sylhet regions are mostly under the agro-ecological zone 20 (Eastern Surma Kushiyara Floodplain) and the soils of this region are strongly acidic. The climate of this region is suitable for potato, tomato, cabbage, aroids and other vegetable production (Nazrul and Shaheb. 2014; Nazrul et al., 2013a; Nazrul et al., 2013b; Shaheb et al., 2012; Sarker, et al., 2012). In addition, agriculture is the only economic activity of most small farmers in this region. But strong soil acidity is an important factor that adversely affecting crop production. Use of liming materials to correct the soil acidity is an important aspect of soil management practice. Thus, lime application improved crop yields by eliminating the production constraints and favoring the production factors related to nutrient availability (Shaheb et al., 2014; Rahman et al., 2013; Rahman et al., 2005). Cabbage (Brassica oleracea var. capitata) and Cauliflower (Brassica oleracea var. botrytis) are cole vegetables crops which are grown better in pH 6.0- 6.8 (Knott 1962), but Eastern Surma Kushiyara 
Nazrul et al.

Floodplain soil is non-calcareous grey which have low $\mathrm{pH}(<5)$ so, liming is needed to increase $\mathrm{pH}$ for better performance of the crops. Liming raises soil $\mathrm{pH}$ and reduces the toxic effect of $\mathrm{Al}, \mathrm{Fe}$ and $\mathrm{Mn}$ and increases the availability of $\mathrm{P}, \mathrm{Mo}, \mathrm{Ca}$, and $\mathrm{Mg}$ (Bodruzzaman, 2010; FRG, 2012). Several other reports (Mongia et al., 1998; Rahman et al., 2000; Rahman et al., 2002, and Rahman et al., 2004) also suggest that liming eliminated the toxic effect of aluminum and manganese and increased the availability of several plant nutrients, such as $\mathrm{Ca}, \mathrm{Mg}, \mathrm{P}, \mathrm{N}$, and Mo. Numerous researches have confirmed the positive impact of liming on yield of some crops (Rastija et al., 2010; Shaheb et al., 2014; Rahman et al., 2013; Rahman et al., 2005). At present, farmers in this area use agricultural lime or dolomite in different quantities to correct the soil acidity. But, initial high cost involvement in liming practice makes exploring the benefit of liming difficult for the marginal growers. The experiments were therefore, designed to find out the suitable levels of dolomite lime and fertilizer management options for better yield of cabbage and cauliflower in acidic soils under the AEZ 20 of Sylhet region.

\section{Materials and Methods}

An experiment was conducted under farmer's fields located at FSRD site, Jalalpur and MLT sites, Moulvibazar and Zokigonj during 2013-2015 to study the effect of lime and fertilizer on the yield of cabbage and cauliflower in acidic soil of Sylhet. The study area lays $24^{0} 70^{\prime} \mathrm{N}$ latitude and $91^{\circ} 67^{\prime} \mathrm{E}$ longitude under the Surma-Kusiyara Floodplain of Bangladesh. Before starting the experiment, initial soil samples were collected from each farmer's field and analyzed in the laboratory of Soil Resource and Development Institute, Sylhet.

Type of experimental soil is non-calcareous grey with low organic matter content $(1.29 \%)$, low soil $\mathrm{pH}(4.2-5.1)$, very low total $\mathrm{N}(0.06 \%)$, low content of $\mathrm{P}(8.59 \mu \mathrm{g} / \mathrm{g}$ soil), $\mathrm{K}$ $(0.13 \mathrm{meq} / 100 \mathrm{~g}$ soil) and $\mathrm{S}(9.14 \mu \mathrm{g} / \mathrm{g}$ soil) where as $\mathrm{Zn}(1.22 \mu \mathrm{g} / \mathrm{g}$ soil $)$ and $\mathrm{B}(0.48 \mu \mathrm{g} / \mathrm{g}$ soil) medium and optimum, respectively. Trials were laid out in a factorial randomized block design with six dispersed replications where 2 fertilizer managements levels were $M_{1}$. soil test based (STB) recommended fertilizer and $M_{2}$. Fertilizer dose practiced by the farmers (FP) and 3 level of limes viz., $\mathrm{L}_{1-} 0 \mathrm{t} \mathrm{ha}^{-1}, \mathrm{~L}_{2^{-}} 1 \mathrm{t} \mathrm{ha}^{-1}$ and $\mathrm{L}_{3^{-}} 2 \mathrm{t} \mathrm{ha} \mathrm{h}^{-1}$ as treatment variables. The dolomite lime $\left(\mathrm{CaO}=30 \%, \mathrm{MgO}=22 \%\right.$ and $\mathrm{CO}_{2}=48 \%$ ) was applied $15-20$ days before planting with spread method on the top of the soil and then incorporate with the soil depth at $25 \mathrm{~cm}$ by plough. The crops wise fertilizers nutrients N P K S Zn (cabbage - $M_{1}$ : 201-63-6523-0.5, $\mathrm{M}_{2}$ : 220-70-70-40-0 and cauliflower - $\mathrm{M}_{1}$ : 157-57-116-20-0.5, $\mathrm{M}_{2}$ : 170-43-136-0-0 Kg $\mathrm{ha}^{-1}$ ) were calculated as per the initial nutrient status of the experimental soil and average fertilizer doses practiced by 25 farmers. Fertilizers were applied in the form of Urea, TSP, MoP, Gypsum and Zinc sulphate, respectively. Half of urea and all other fertilizers were applied and mixed with soil at the time of final land preparation. Rest urea was top dressed at 25 days after transplanting. Seedlings of cabbage (var. Atlas-70) and cauliflower (var. Canditcharm) at the age of 30 days were planted on a plot size of $5 \mathrm{~m} \times 4 \mathrm{~m}$ with plant spacing of $60 \mathrm{~cm} \times 40 \mathrm{~cm}$. The crops were harvested 80-95 days after planting (DAP). Twice irrigations one of each at 25 days interval from the transplant of seedlings; one weeding at 20 DAP; two sprayings of secure fungicide @ 1.5 $\mathrm{mL}^{-1}$ of water for controlling blight of crops. All intercultural operations were done as when necessary. The head and curd yield of cabbage and cauliflower were recorded from 10 randomly selected plants from each plot and yield of crops were recorded from whole plot basis at harvest. The recorded data were statistically analyzed and mean values were separated by least significant difference test (LSD). All types of variable costs of production were recorded and cost-benefit analysis was carried out (Heady and Dhillon, 1988). 
Integrated Approach For Liming And Fertilizer Application On Yield Of Cabbage And Cauliflower

\section{Results and Discussions}

\section{Location: Jalalpur}

Head yield of cabbage: Results revealed that significant response was found on fertilizer management and application of lime and their interactions on the head and curd yields of cabbage and cauliflower respectively. The average maximum head yield of cabbage $(65.01 \mathrm{t}$ $\mathrm{ha}^{-1}$ ) was recorded in soil test based (STB) $\left(\mathrm{M}_{1}\right)$ compared to fertilizer dose of the farmers $\left(\mathrm{M}_{2}\right)$. the maximum head yield $\left(66.22 \mathrm{t} \mathrm{ha}^{-1}\right)$ of cabbage was found in $2 \mathrm{t} \mathrm{ha}^{-1}$ of dolomite $\left(L_{3}\right)$ that was followed by $1 \mathrm{t} \mathrm{ha}^{-1}\left(\mathrm{~L}_{2}\right)$ of dolomite lime. Khandakhar et al., (2004) also reported that @2 t ha ${ }^{-1}$ of $\mathrm{Ca}(\mathrm{OH})_{2}$ along with $100 \mathrm{~kg} \mathrm{~K}$ ha $^{-1}$ is recommended for potato cultivation under strongly acidic soil. whole non-liming treatment produced the lowest yield (56.04 $\mathrm{t} \mathrm{ha}^{-1}$ ) of cabbage. The results revealed that combined effect of STB and $2 \mathrm{t} \mathrm{ha}^{-1}$ of dolomite lime $\left(M_{1} L_{3}\right)$ provided the maximum average head yield of cabbage $\left(70.90\right.$ tha $\left.^{-1}\right)$ that was statistically followed by $M_{1} L_{2}$ with yield of $66.49 \mathrm{t} \mathrm{ha}^{-1}$ (Table 1).

Table 1. Effect of fertilizer management and levels of liming on the head and curd yield of cabbage and cauliflowerat Jalalpur, Sylhet (2013-2015)

\begin{tabular}{|c|c|c|c|c|c|c|}
\hline \multirow[t]{2}{*}{ Treatments } & \multicolumn{3}{|c|}{ Head yield $\left(\mathrm{t} \mathrm{ha}^{-1}\right)$} & \multicolumn{3}{|c|}{ Curd yield $\left(\mathrm{t} \mathrm{ha}^{-1}\right)$} \\
\hline & $2013-2014$ & $2014-2015$ & Average & 2013-2014 & 2014-2015 & Average \\
\hline \multicolumn{7}{|c|}{ A. Fertilizer management } \\
\hline $\mathrm{M}_{1}$ & 67.71 & 62.30 & 65.01 & 44.39 & 60.40 & 52.4 \\
\hline$M_{2}$ & 62.24 & 54.69 & 58.47 & 43.88 & 49.08 & 46.48 \\
\hline CV (\%) & 2.53 & 8.87 & 5.70 & 4.33 & 12.97 & 8.65 \\
\hline \multicolumn{7}{|c|}{ B. Level of liming } \\
\hline$L_{1}$ & 58.46 & 53.61 & 56.04 & 40.90 & 53.93 & 47.42 \\
\hline $\mathrm{L}_{2}$ & 67.16 & 58.75 & 62.96 & 43.59 & 53.71 & 48.65 \\
\hline $\mathrm{L}_{3}$ & 69.31 & 63.12 & 66.22 & 47.92 & 56.57 & 52.25 \\
\hline CV (\%) & 2.53 & 8.87 & 5.7 & 4.33 & 12.97 & 8.65 \\
\hline $\operatorname{LSD}_{(0.05)}$ & 2.48 & 7.82 & 5.15 & 5.81 & NS & 5.81 \\
\hline \multicolumn{7}{|c|}{ Fertilizer management $\times$ Level of liming } \\
\hline$M_{1} L_{1}$ & 59.55 & 55.67 & 57.61 & 40.25 & 59.26 & 49.76 \\
\hline$M_{1} L_{2}$ & 70.50 & 62.48 & 66.49 & 43.25 & 58.32 & 50.79 \\
\hline$M_{1} L_{3}$ & 73.07 & 68.73 & 70.9 & 49.66 & 63.61 & 56.64 \\
\hline$M_{2} L_{1}$ & 57.37 & 51.55 & 54.46 & 41.55 & 48.61 & 45.08 \\
\hline $\mathrm{M}_{2} \mathrm{~L}_{2}$ & 63.83 & 55.02 & 59.43 & 43.93 & 49.10 & 46.52 \\
\hline $\mathrm{M}_{2} \mathrm{~L}_{3}$ & 65.54 & 57.50 & 61.52 & 46.17 & 49.52 & 47.85 \\
\hline CV (\%) & 2.53 & 8.87 & 5.7 & 4.33 & 12.97 & 8.65 \\
\hline $\operatorname{LSD}_{(0.05)}$ & 2.48 & 7.82 & 5.15 & 2.88 & 10.70 & 6.79 \\
\hline
\end{tabular}

$\mathrm{M}_{1}$ : Soil test based (STB) recommended fertilizer and $\mathrm{M}_{2}$ : Fertilizer dose practiced by farmers (FP) and Level of limes $L_{1}: 0 t$ ha $^{-1}, L_{2}: 1 \mathrm{tha}^{-1}$ and $\mathrm{L}_{3}: 2 \mathrm{t} \mathrm{ha}{ }^{-1}$

Curd yield of cauliflower: The STB fertilizer dose $\left(\mathrm{M}_{1}\right)$ provided higher curd yield of cauliflower (52.40 tha ${ }^{-1}$ ) as compared to yield of the farmers $\left(M_{2}\right)$. Considering the application of lime doses, the highest average curd yield (52.25 t ha $\left.\mathrm{h}^{-1}\right)$ of cauliflower was found in $2 \mathrm{t} \mathrm{ha}^{-1}$ of dolomite lime $\left(L_{3}\right)$ that was followed by $L_{2}\left(48.65 \mathrm{t} \mathrm{ha}^{-1}\right)$. But, the lowest 
Nazrul et al.

yield (47.42 $\mathrm{t} \mathrm{ha}^{-1}$ ) was observed in $\mathrm{L}_{1}$ (zero liming). Application of dolomite could increase soil pH from 4.9 to 5.4 with increase $\mathrm{Ca}$ and $\mathrm{Mg}$ stock in the soil (Oliveira et al., 2003; Thompson and Kelly 1957). The situation made cauliflower to perform good vegetative growth because it is sensitive on $\mathrm{pH}$ level and high dose of $\mathrm{Mg}$ reported by Thompson and Kelly (1957). The combined application of STBand $2 t$ ha ${ }^{-1}$ of dolomite lime $\left(M_{1} L_{3}\right)$ gave the maximum curd yield of cauliflower $\left(56.64 \mathrm{t} \mathrm{ha}^{-1}\right)$ which was statistically identical to $M_{1} L_{2}$ $\left(50.79 \mathrm{t} \mathrm{ha}^{-1}\right)$. However, the lowest curd yield $\left(45.08 \mathrm{t} \mathrm{ha}^{-1}\right)$ of cauliflower was produced by the treatment combination of $\mathrm{M}_{2} \mathrm{~L}_{1}$ (Table 1).

Cost and return analysis: The gross return, total cost and net return of different combinations are presented in Table 2. From the cost benefit analysis, it was exhibited that maximum gross return (Tk. 567200 and Tk. 566400 ha $^{-1}$ ) and net return (Tk. 385777 and Tk. $401067 \mathrm{ha}^{-1}$ ) was obtained from the combination of $\mathrm{M}_{1} \mathrm{~L}_{3}$ for cabbage and cauliflower, respectively. The lowest values of the same economic parameters were observed in combination of $M_{2} L_{1}$ (Table 2). The economic analysis also revealed that the highest values (3.13 and 3.43) of benefit cost ratio (BCR) were obtained in case of both vegetables under the same treatment $\left(M_{1} L_{3}\right)$.

Table 2. Cost and return analysis of fertilizer management with levels of limes on the yield of cabbage and cauliflower at Jalalpur in Sylhet (2013-2015)

\begin{tabular}{|c|c|c|c|c|c|c|c|c|}
\hline \multirow[t]{2}{*}{ Treatments } & \multicolumn{4}{|c|}{ Cabbage } & \multicolumn{4}{|c|}{ Cauliflower } \\
\hline & $\begin{array}{c}\text { GR } \\
\left(\text { Tk.ha }^{-1}\right)\end{array}$ & $\begin{array}{c}\text { TC } \\
\left(\text { Tk.ha }^{-1}\right)\end{array}$ & $\begin{array}{c}\text { GM } \\
\left(\text { Tk.h }^{-1}\right)\end{array}$ & BCR & $\begin{array}{c}\text { GR } \\
\left(T^{-1} \cdot h^{-1}\right)\end{array}$ & $\begin{array}{c}\text { TC } \\
\left(\text { Tk.ha }^{-1}\right)\end{array}$ & $\begin{array}{c}\text { GM } \\
\left(\text { Tk.ha }^{-1}\right)\end{array}$ & BCR \\
\hline$M_{1} L_{1}$ & 460880 & 172123 & 288757 & 2.68 & 497600 & 156033 & 341567 & 3.19 \\
\hline$M_{1} L_{2}$ & 531920 & 177023 & 354897 & 3.00 & 507900 & 160933 & 346967 & 3.16 \\
\hline$M_{1} L_{3}$ & 567200 & 181423 & 385777 & 3.13 & 566400 & 165333 & 401067 & 3.43 \\
\hline $\mathrm{M}_{2} \mathrm{~L}_{1}$ & 435680 & 166268 & 269412 & 2.62 & 450800 & 153638 & 297162 & 2.93 \\
\hline $\mathrm{M}_{2} \mathrm{~L}_{2}$ & 475440 & 171168 & 304272 & 2.78 & 465200 & 158538 & 306662 & 2.93 \\
\hline $\mathrm{M}_{2} \mathrm{~L}_{3}$ & 492160 & 175568 & 316592 & 2.80 & 478500 & 162938 & 315562 & 2.94 \\
\hline
\end{tabular}

GR: Gross return (Tk.ha $\left.{ }^{-1}\right)$, TC: Total cost $\left(\right.$ Tk.ha $\left.^{-1}\right)$ and GR: Gross margin (Tk.ha ${ }^{-1}$ )

Price of input and output $\left(\mathrm{Tk}_{\mathrm{Kg}}{ }^{-1}\right)$ : Dolomite lime- 5.00, Urea-20.00, TSP-22.00, MoP-15.00, Cowdung-1.00, Cabbage-8.00, Cauliflower-10.00

\section{Location: Zokigonj}

It was observed that the doses of fertilizer management and dolomite levels and their interactions on the head and curd yield of cabbage and cauliflower were influenced significantly.(Table 3).

Head yield of cabbage: The average head yield $\left(66.58 \mathrm{tha}^{-1}\right)$ of cabbage with STB fertilizer dose t was higher than cabbage fertilized with farmer's practices. Among the dolomite levels, 2 tha $^{-1}\left(\mathrm{~L}_{3}\right)$ contributed the maximum head yield $\left(68.05 \mathrm{t} \mathrm{ha}^{-1}\right)$ of cabbage which was statistically identical to $1 \mathrm{tha}^{-1}\left(\mathrm{~L}_{2}\right)$ of dolomite. Non liming treatment $\left(\mathrm{L}_{1}\right)$ produced the lowest average head yield of cabbage $\left(60.84 \mathrm{tha}^{-1}\right)$. It was found that combination of STB recommended fertilizer management and $2 \mathrm{t} \mathrm{ha}^{-1}$ of dolomite limes $\left(M_{1} L_{3}\right)$ gave the maximum head yield of cabbage ( 71.25 tha $^{-1}$ ) that was statistically followed by $M_{1} L_{2}$ with yield of $65.92 \mathrm{t} \mathrm{ha}^{-1}$.It was reported that liming material increases the cation exchange 
Integrated Approach For Liming And Fertilizer Application On Yield Of Cabbage And Cauliflower

capacity of soil and also increase nutrient content such as $\mathrm{P}$ and $\mathrm{K}$ (Kisic et al., 2004b). It was assumed that application of dolomite lime increase soil $\mathrm{pH}$; which helps to improve nutrients for the vegetables resulted increased the growth and yield of cabbage.

Curd yield of cauliflower: The average higher curd yield of cauliflower (49.42 $\left.\mathrm{t} \mathrm{ha}^{-1}\right)$ was recorded in STB recommended fertilizer $\left(M_{1}\right)$ compared to farmers practice $\left(M_{2}\right)$. On the contrary, significantly higher curd yield $\left(50.83 \mathrm{t} \mathrm{ha}^{-1}\right)$ of cauliflower was produced by $\mathrm{L}_{3}$ compared to $L_{2}$ and without lime. Results of combined application of STB recommended fertilizer management and $2 \mathrm{t} \mathrm{ha}^{-1}$ of dolomite showed that the highest curd yield of cauliflower (54.90 $\mathrm{t} \mathrm{ha}^{-1}$ ) was recorded that was statistically followed by $\mathrm{M}_{1} \mathrm{~L}_{2}\left(47.93 \mathrm{t} \mathrm{ha}^{-1}\right)$. However, the treatment combination $\left(\mathrm{M}_{2} \mathrm{~L}_{1}\right)$ was provided the lowest curd yield $\left(40.69 \mathrm{t} \mathrm{ha}^{-1}\right)$ of cauliflower (Table 3).

Table 3. Effect of fertilizer management and level of liming on the head and curd yield of cabbage and cauliflower, respectively at Zokigonj in acidic soil of Sylhet (20132015)

\begin{tabular}{|c|c|c|c|c|c|c|}
\hline \multirow{2}{*}{$\begin{array}{c}\text { Treatment } \\
\mathrm{s}\end{array}$} & \multicolumn{3}{|c|}{ Head yield } & \multicolumn{3}{|c|}{ Curd yield } \\
\hline & 2013-2014 & 2014-2015 & Average & 2013-2014 & $2014-2015$ & Average \\
\hline \multicolumn{7}{|c|}{ A. Fertilizer management } \\
\hline$M_{1}$ & 63.72 & 69.44 & 66.58 & 50.03 & 48.81 & 49.42 \\
\hline$M_{2}$ & 60.61 & 62.44 & 61.525 & 43.64 & 43.14 & 43.39 \\
\hline CV (\%) & 1.80 & 8.24 & 5.02 & 8.91 & 2.67 & 5.79 \\
\hline \multicolumn{7}{|c|}{ B. Level of liming } \\
\hline $\mathrm{L}_{1}$ & 60.00 & 61.67 & 60.84 & 43.90 & 42.22 & 43.06 \\
\hline $\mathrm{L}_{2}$ & 62.58 & 64.00 & 63.29 & 46.33 & 44.33 & 45.33 \\
\hline$L_{3}$ & 63.92 & 72.17 & 68.05 & 50.28 & 51.38 & 50.83 \\
\hline CV (\%) & 1.80 & 8.24 & 5.02 & 8.91 & 2.67 & 5.79 \\
\hline $\operatorname{LSD}_{(0.05 \%)}$ & NS & 9.89 & 9.89 & NS & 2.23 & 2.23 \\
\hline \multicolumn{7}{|c|}{ Fertilizer management $\times$ Level of liming } \\
\hline$M_{1} L_{1}$ & 61.17 & 64.00 & 62.59 & 46.43 & 44.43 & 45.43 \\
\hline$M_{1} L_{2}$ & 63.50 & 68.33 & 65.92 & 49.33 & 46.53 & 47.93 \\
\hline$M_{1} L_{3}$ & 66.50 & 76.00 & 71.25 & 54.33 & 55.47 & 54.90 \\
\hline $\mathrm{M}_{2} \mathrm{~L}_{1}$ & 58.83 & 59.33 & 59.08 & 41.37 & 40.00 & 40.69 \\
\hline $\mathrm{M}_{2} \mathrm{~L}_{2}$ & 61.67 & 59.67 & 60.67 & 43.33 & 42.13 & 42.73 \\
\hline $\mathrm{M}_{2} \mathrm{~L}_{3}$ & 61.33 & 68.33 & 64.83 & 46.23 & 47.30 & 46.77 \\
\hline CV (\%) & 1.80 & 8.24 & 5.02 & 8.91 & 2.67 & 5.79 \\
\hline $\operatorname{LSD}_{(0.05 \%)}$ & 2.04 & 9.89 & 5.965 & 7.59 & 2.23 & 4.91 \\
\hline
\end{tabular}

$\mathrm{M}_{1}$ : Soil test based (STB) recommended fertilizer and $\mathrm{M}_{2}$ : Fertilizer dose practiced by farmers (FP) and Level of limes $L_{1}: 0 \mathrm{tha}^{-1}, \mathrm{~L}_{2}: 1 \mathrm{t} \mathrm{ha}^{-1}$ and $\mathrm{L}_{3}: 2 \mathrm{t} \mathrm{ha}^{-1}$

Cost and return analysis : Dolomite, $2 \mathrm{t} \mathrm{ha}^{-1}$ with fertilizer nutrients $\mathrm{N}_{201}, \mathrm{P}_{63}, \mathrm{~K}_{65}, \mathrm{~S}_{23}, \mathrm{Zn}_{0.5}$ and $\mathrm{N}_{157}, \mathrm{P}_{57}, \mathrm{~K}_{116}, \mathrm{~S}_{20}, \mathrm{Zn}_{0.5} \mathrm{Kg}$ ha ${ }^{-1}$ was contributed the highest net returns (Tk. 426577 and Tk. 383667 ha-1) from cabbage and cauluflower, respectively (Table 4). Fertilizer package practiced by the farmers without lime application provided lowest economic profit of both vegetables. 
Nazrul et al.

Table 4. Cost and return analysis of fertilizer management with levels of limes on the yield of cabbage and cauliflower at Zokigonj, Sylhet (2013-2015)

\begin{tabular}{c|c|c|c|c|c|c|c|c}
\hline Treatments & \multicolumn{4}{|c|}{ Cabbage } & & \multicolumn{4}{c}{ Cauliflower } \\
\cline { 2 - 9 } & $\begin{array}{c}\text { GR } \\
\left(\text { Tk.ha }^{-1}\right)\end{array}$ & $\begin{array}{c}\text { TC } \\
\left(\text { Tk.ha }^{-1}\right)\end{array}$ & $\begin{array}{c}\text { GM } \\
\left(\text { Tk.ha }^{-1}\right)\end{array}$ & BCR & $\begin{array}{c}\text { GR } \\
\left(\text { Tk.ha }^{-1}\right)\end{array}$ & $\begin{array}{c}\text { TC } \\
\left(\text { Tk.ha }^{-1}\right)\end{array}$ & $\begin{array}{c}\text { GM } \\
\left(\text { Tk.ha }^{-1}\right)\end{array}$ & BCR \\
\hline $\mathrm{M}_{1} \mathrm{~L}_{1}$ & 500720 & 172123 & 328597 & 2.91 & 454300 & 156033 & 298267 & 2.91 \\
$\mathrm{M}_{1} \mathrm{~L}_{2}$ & 527360 & 177023 & 350337 & 2.98 & 479300 & 160933 & 318367 & 2.98 \\
$\mathrm{M}_{1} \mathrm{~L}_{3}$ & 570000 & 181423 & 388577 & 3.14 & 549000 & 165333 & 383667 & 3.32 \\
$\mathrm{M}_{2} \mathrm{~L}_{1}$ & 472640 & 166268 & 306372 & 2.84 & 406900 & 153638 & 253262 & 2.65 \\
$\mathrm{M}_{2} \mathrm{~L}_{2}$ & 485360 & 171168 & 314192 & 2.84 & 427300 & 158538 & 268762 & 2.70 \\
$\mathrm{M}_{2} \mathrm{~L}_{3}$ & 518640 & 175568 & 343072 & 2.95 & 467700 & 162938 & 304762 & 2.87 \\
\hline
\end{tabular}

GR: Gross return (Tk.ha $\left.{ }^{-1}\right)$, TC: Total cost $\left(\right.$ Tk. ha $\left.^{-1}\right)$ and GM: Gross margin (Tk.ha ${ }^{-1}$ )

Price of input and output $\left(\mathrm{Tk}_{\mathrm{Kg}} \mathrm{K}^{-1}\right)$ : Dolomite lime- 5.00, Urea-20.00, TSP-22.00, MoP-15.00, Cowdung-1.00, Cabbage-8.00, Cauliflower-10.00

\section{Location: Moulvibazar}

Head yield of cabbage: Fertilizer application affected head yield of cabbage where maximum head yield $\left(62.89 \mathrm{t} \mathrm{ha}^{-1}\right)$ was produced by STB fertilizer management $\left(\mathrm{M}_{1}\right)$ compared to farmers dose $\left(\mathrm{M}_{2}\right)$.

The head yield of cabbage was increased by increasing the rates of limewhere 2 tha $^{-1}$ produced higher yield than the other rate of lime and no liming. The STB recommended fertilizer management with $2 \mathrm{t} \mathrm{ha}{ }^{-1}$ of dolomite lime $\left(M_{1} L_{3}\right)$ produced maximum head yield $\left(65.49 \mathrm{t} \mathrm{ha}^{-1}\right)$ that was followed by $\mathrm{M}_{1} \mathrm{~L}_{2}\left(64.88 \mathrm{t} \mathrm{ha}^{-1}\right)$, while the lowest head yield $(51.59 \mathrm{t}$ ha $\left.{ }^{1}\right)$ was gained in the treatment combination of $M_{2} L_{1}$ (Table 5). Sultana et al., (2009) reported that the grain yield of wheat was increased due to application of $2.0 \mathrm{t} \mathrm{ha}^{-1}$ lime at low soil pH $(>6.0)$.

Curd yield of cauliflower: It was observed that the effect of fertilizer management on the curd yield of cauliflower was significant. The higher curd yield $\left(45.31 \mathrm{t} \mathrm{ha}^{-1}\right)$ was recorded in STB recommended fertilizer management $\left(M_{1}\right)$ compared to farmers dose $\left(M_{2}\right)\left(39.33\right.$ tha $\left.{ }^{-1}\right)$ although yields were non-significant. The level of dolomite, $2 \mathrm{t} \mathrm{ha}^{-1}\left(\mathrm{~L}_{3}\right)$ gave the maximum curd yield $\left(45.67 \mathrm{t} \mathrm{ha}^{-1}\right)$ which was statistically followed by $1 \mathrm{t} \mathrm{ha}^{-1}\left(\mathrm{~L}_{2}\right)$ of dolomite lime. On the contrary, the lowest curd yield $\left(39.57 \mathrm{t} \mathrm{ha}^{-1}\right)$ of cauliflower was observed in without lime $\left(L_{1}\right)$. The interacxtion result showed that the maximum average curd yield $\left(48.88 \mathrm{tha}^{-1}\right)$ was recorded in $M_{1} L_{3}$ that was statistically followed by $M_{1} L_{2}\left(44.56 \mathrm{t} \mathrm{ha}^{-1}\right)$ while lowest yield $\left(36.66 \mathrm{t} \mathrm{ha}^{-1}\right)$ from farmers practice without dolomite.(Table 5).

Table 5. Effect of fertilizer management and level of liming on the head and curd yield of cabbage and cauliflower, respectively at Moulvibazar in acidic soil of Sylhet (20132015)

\begin{tabular}{c|c|c|c|c|c|c}
\hline \multirow{2}{*}{$\begin{array}{c}\text { Treatment } \\
\text { s }\end{array}$} & \multicolumn{3}{|c|}{ Head yield } & \multicolumn{3}{c}{ Curd yield } \\
\cline { 2 - 6 } & $2013-2014$ & $2014-2015$ & Average & $2013-2014$ & $2014-2015$ & Average \\
\hline \multicolumn{6}{c}{ A. Fertilizer management } \\
\hline
\end{tabular}


Integrated Approach For Liming And Fertilizer Application On Yield Of Cabbage And Cauliflower

\begin{tabular}{ccccccc}
\hline $\mathrm{M}_{1}$ & 66.16 & 59.62 & 62.89 & 50.00 & 40.61 & 45.31 \\
$\mathrm{M}_{2}$ & 57.52 & 53.70 & 55.61 & 46.40 & 32.25 & 39.33 \\
\hline $\mathrm{CV}(\%)$ & 6.48 & 3.34 & 4.91 & 5.85 & 8.73 & 7.29 \\
\hline \multicolumn{7}{c}{ B. Level of liming } \\
\hline $\mathrm{L}_{1}$ & 56.31 & 53.57 & 54.94 & 45.38 & 33.75 & 39.57 \\
$\mathrm{~L}_{2}$ & 65.13 & 56.17 & 60.65 & 47.67 & 35.77 & 41.72 \\
$\mathrm{~L}_{3}$ & 64.07 & 60.23 & 62.15 & 51.55 & 39.76 & 45.67 \\
\hline $\mathrm{CV}(\%)$ & 6.48 & 3.34 & 4.91 & 5.85 & 8.73 & 7.29 \\
$\mathrm{LSD}(0.05 \%)$ & 7.29 & 3.45 & 5.37 & $\mathrm{NS}$ & $\mathrm{NS}$ & $\mathrm{NS}$ \\
\hline \multicolumn{7}{c}{ Fertilizer management $\times$ Level of liming } \\
\hline $\mathrm{M}_{1} \mathrm{~L}_{1}$ & 59.81 & 56.78 & 58.30 & 46.45 & 38.47 & 42.46 \\
$\mathrm{M}_{1} \mathrm{~L}_{2}$ & 60.27 & 59.48 & 59.88 & 49.43 & 39.69 & 44.56 \\
$\mathrm{M}_{1} \mathrm{~L}_{3}$ & 68.38 & 62.59 & 65.49 & 54.10 & 43.65 & 48.88 \\
$\mathrm{M}_{2} \mathrm{~L}_{1}$ & 52.81 & 50.37 & 51.59 & 44.30 & 29.02 & 36.66 \\
$\mathrm{M}_{2} \mathrm{~L}_{2}$ & 59.98 & 52.85 & 56.42 & 45.90 & 31.85 & 38.88 \\
$\mathrm{M}_{2} \mathrm{~L}_{3}$ & 59.76 & 57.87 & 58.82 & 49.00 & 35.87 & 42.44 \\
\hline $\mathrm{CV}(\%)$ & 6.48 & 3.34 & 4.91 & 5.85 & 8.73 & 7.29 \\
$\mathrm{LSD}(0.05 \%)$ & 7.29 & 3.45 & 5.37 & 5.13 & 5.78 & 5.455 \\
\hline
\end{tabular}

$\mathrm{M}_{1}$ : Soil test based (STB) recommended fertilizer and $\mathrm{M}_{2}$ : Fertilizer dose practiced by farmers (FP) and Level of limes $\mathrm{L}_{1}: 0 \mathrm{tha}{ }^{-1}, \mathrm{~L}_{2}: 1 \mathrm{t} \mathrm{ha}^{-1}$ and $\mathrm{L}_{3}: 2 \mathrm{t} \mathrm{ha}^{-1}$

Cost and return analysis : The cost benefit analysis exhibited that maximum gross return (Tk. 523920 and Tk. 488800 ha $^{-1}$ ) and net return (Tk. 342497 and Tk. 323467 ha $^{-1}$ ) was obtained from the treatment combination of STB recommended fertilizer management with dolomite $2 \mathrm{t} \mathrm{ha}^{-1}\left(\mathrm{M}_{1} \mathrm{~L}_{3}\right)$ with higher benefit cost ratios (2.89 and 2.96) for cabbage and cauliflower, respectively. However, the treatment combinations without lime $\left(M_{1} L_{1}, M_{2} L_{1}\right)$ contribute lower economic returns (Table 6).

Table 6. Cost and return analysis of fertilizer management with levels of lime on the cultivation of cabbage and cauliflower at Moulvibazar, Sylhet (2013-2015)

\begin{tabular}{c|c|c|c|c|c|c|c|c}
\hline Treatments & \multicolumn{4}{|c|}{ Cabbage } & \multicolumn{4}{c}{ Cauliflower } \\
\cline { 2 - 9 } & $\begin{array}{c}\text { GR } \\
\left(\text { Tk.ha }^{-1}\right)\end{array}$ & $\begin{array}{c}\text { TC } \\
\left(\text { Tk.ha }^{-1}\right)\end{array}$ & $\begin{array}{c}\text { GM } \\
\left(\text { Tk.ha }^{-1}\right)\end{array}$ & BCR & $\begin{array}{c}\text { GR } \\
\left(\text { Tk.ha }^{-1}\right)\end{array}$ & $\left.\begin{array}{c}\text { TC } \\
\left(\text { Tk.ha }^{-1}\right)\end{array}\right)$ & $\begin{array}{c}\text { GM } \\
\left(\text { Tk.ha }^{-1}\right)\end{array}$ & BCR \\
\hline $\mathrm{M}_{1} \mathrm{~L}_{1}$ & 466400 & 172123 & 294277 & 2.71 & 424600 & 156033 & 268567 & 2.72 \\
$\mathrm{M}_{1} \mathrm{~L}_{2}$ & 519040 & 177023 & 342017 & 2.93 & 445600 & 160933 & 284667 & 2.77 \\
$\mathrm{M}_{1} \mathrm{~L}_{3}$ & 523920 & 181423 & 342497 & 2.89 & 488800 & 165333 & 323467 & 2.96 \\
$\mathrm{M}_{2} \mathrm{~L}_{1}$ & 412720 & 166268 & 246452 & 2.48 & 366600 & 153638 & 212962 & 2.39 \\
$\mathrm{M}_{2} \mathrm{~L}_{2}$ & 435360 & 171168 & 264192 & 2.54 & 388800 & 158538 & 230262 & 2.45 \\
$\mathrm{M}_{2} \mathrm{~L}_{3}$ & 470560 & 175568 & 294992 & 2.68 & 424400 & 162938 & 261462 & 2.60 \\
\hline
\end{tabular}

GR: Gross return (Tk.ha' $\left.{ }^{-1}\right)$, TC: Total cost $\left(\right.$ Tk.ha $\left.^{-1}\right)$ and GM: Gross margin(Tk.ha $\left.{ }^{-1}\right)$

Price of input and output $\left(\mathrm{Tk}_{\mathrm{Kg}}{ }^{-1}\right)$ : Dolomite lime- 5.00, Urea-20.00, TSP-22.00, MoP-15.00, Cowdung-1.00, Cabbage-8.00, Cauliflower-10.00

\section{Conclusion}

The results revealed that the maximum head yield of cabbage and curd yield of cauliflower was obtained with the application of STB recommended fertilizer $\left(\mathrm{N}_{201}, \mathrm{P}_{63}, \mathrm{~K}_{65}, \mathrm{~S}_{23}, \mathrm{Zn}_{0.5}\right.$ for cabbage and $\mathrm{N}_{157}, \mathrm{P}_{57}, \mathrm{~K}_{116}, \mathrm{~S}_{20}, \mathrm{Zn}_{0.5} \mathrm{Kg} \mathrm{ha}^{-1}$ for cauliflower). Liming at the rate $2 \mathrm{t} \mathrm{ha}^{-1}$ supported for the highest yields of cabbage and cauliflower in both the years in all the locations but identical to that of $1 \mathrm{t} \mathrm{ha}^{-1}$ of dolomite lime with similar dose of fertilizers Therefore, application of lime at the rate $1 \mathrm{t} \mathrm{ha}^{-1}$ with recommended fertilizer might be 
Nazrul et al.

effective for economic productivity of both the cabbage and cauliflower in the acidic soils of the greater Sylhet region.

\section{References}

Bodruzzaman, M. 2010. Lime requirement of acid soils for sustainable crop production. Ph. D. Thesis. BAU, Mymensingh, Bangladesh. p. 310.

FRG. 2012. Fertilizer Recommendation Guide, Bangladesh Agriculture Research Council (BARC), Farmgate, Dhaka 1215. p. 274.

Heady, E. O. and J. L. Dillon. 1988. Agricultural Production Functions. Kalyani Publishers. New Delhi, India.

Khandakhar, S. M. A. T., M. M. Rahman, M. J. Uddin, S. A. K. U. Khan and K. G. Quddus. 2004. Effect of Lime and Potassium on Potato Yield in Acid Soil. Pak. J. Biol. Sci., 7(3): 380383.

Kisic I., B. Ferdo, M. Mesic, A. Butaroc and Z. Vadic. 2004b. The effect of fertilization and liming on some soil chemical properties of eutric gleysol. Agric. Cosnspec. Sci. 69(2-3): 43-49.

Knott, J. E. 1962. Hand book for vegetable grower. John Wiley \& Sons, Inc. New York.

Meda A. R., M. A. Pavan, M. E. Cassiolato and M. Miyazawa. 2002. Dolomite lime's reaction applied on the surface of a sandy soil of the Northwest Parana, Brazil. Braz. Arch. Biol. Technol. 45(2): 219-222.

Mongia, A. D., N. T. Singh, L. N. Mandal and A. Guha. 1998. Effect of liming, superphosphate and rock phosphate application to rice on the yield and uptake of nutrients on acid sulphate soils. J. Indian Soc. Soil Sci. 46: 61-66.

Nazrul, M I., M. R. Shaheb and J. U. Sarker. 2013a. Performance of BARI released aroid varieties in Surma Kushiyara Flood Plain Soil. Bangladesh Agron. J. 16 (1):39-44.

Nazrul, M. I. and M. R. Shaheb. 2014. Performance of sweet gourd as relay with transplanted aman rice under rainfed ecosystem in Sylhet region. Bangladesh Agron. J. 17(2): 47-53.

Nazrul, M. I., M. R. Shaheb, M. A. H. Khan and A. S. M. M. R. Khan. 2013b. On-farm evaluation of production potential and economic returns of potato-rice based improved cropping system. Bangladesh Agron. J. 16 (2): 41-50.

Oliveira, P. P. A., A. E. Boaretto, P. C. O. Trivelin, W. S. de Oliveira and M. Corsi. 2003. Liming and fertilization to restore degraded Brachiaria decumbens pastures grown on an entisol. Sci. Agric. 60(1): 125-131.

Rahman, M. A., C. A. Meisner, J. M. Duxbury, J. Lauren and A. B. S. Hossain. 2002: Integrated approach of liming and nutrient management to improve the productivity of acidic soil within a rice-wheat cropping system. Poster no.773, Symposium no. $05,17^{\text {th }}$ World Congress of Soil Science. 14-21 August 2002. Bangkok, Thailand.

Rahman, M. A., J. Chikushi, J. G. Lauren, J. M. Duxbury and C. A. Meisner. 2004: Liming and nutrient management for sustainable productivity of acidic alluvial soils under rice-wheat cropping system in Bangladesh. Proc. $6^{\text {th }}$ International symposium on plant-soil interaction at low pH. pp. 304-305. August 1-5, 2004. Sendai, Japan. Organized by International Steering Committee on Soil-Plant Interaction at low pH.

Rahman, M. A., J. Chikushi, J. G. Lauren, J. M. Duxbury, C. A. Meisner, and E. Yasunaga. 2005. Chemical control of soil environment by lime and nutrients to improve the productivity of 
Integrated Approach For Liming And Fertilizer Application On Yield Of Cabbage And Cauliflower

acidic alluvial soils under rice-wheat cropping system. Environ. Control Biol. 43(4): 259266.

Rahman, M. A., M. Bodruzzaman, A. J. M. S. Karim, M. A. Razzaque and C. A. Meisner. 2000. Effect of lime and phosphorus on soil $\mathrm{pH}$, available $\mathrm{P}$ in soil and yield of wheat in acid soil of Dinajpur. Ann. Bangladesh Agric. 10(2):125-131.

Rahman, M. A., N. C. D. Barma, M. H. Sarker, M. M. R. Sarker and M. I. Nazrul. 2013. Adaptability of wheat varieties in strongly acidic soils of Sylhet. Bangladesh J. Agric. Res. 38(1): 97-104.

Rastija, M., D. Šimić and A. Lalić. 2010. Impacts of liming with dolomite on maize, wheat and barley yields. Novenytermeles 59(Suppl.): 65-68.

Sarker, M. M. R., M. R. Shaheb and M. I. Nazrul. 2012. Urea Super Granule: A good source of nitrogen on growth yield and profitability of cabbage in Sylhet. J. Environ. Sci. Natural Resources. 5(1): 295-299.

Shaheb, M. R., M. I. Nazrul and M. A. Rahman. 2014. Production potential and economics of wheat as influenced by liming in north eastern region of Bangladesh. Asian J. Agric. Biol. 2(2): 152-160.

Shaheb, M. R., M. I. Nazrul and M. H. Sarker. 2012. Performance of Tomato varieties as affected by different planting dates in the north-eastern region of Bangladesh. Bangladesh Agron. J. 15(2): 53-58.

Sultana, B. S., M. M. Mian, M. R. Islam, M. M. Rahman, B. C. Sarker and M. S. Zoha. 2009. Effect of liming on soil properties, yield and nutrient uptake by wheat. World Environ. 4(1): 39-47.

Thompson, H. C. and W. C. Kelly. 1957. Vegetable Crops. McGraw-Hill Book Co., New York. p. 611. 